\title{
HOW WILL FUTURE CHALLENGES CHANGE OUR LIFE AT HOME?
}

\author{
Molnár Eszter, ${ }^{1}$ Borsos Ágnes ${ }^{2}$ \\ University of Pécs, Faculty of Engineering and Information Technology, Pécs, Hungary \\ ${ }^{1}$ esztilla11@gmail.com \\ 2agnesborsos@mik.pte.hu
}

\begin{abstract}
Homemaking as a concept is fundamental for all, being a part of life. The foundation of this idea is a key momentum in everyday life. With the growth of a city's population, the demand for increased of living space and buildings will increase too. In a city, green spaces are a matter of high importance regarding their positive impact. Keeping these we give a further meaning to creating living spaces. In the process we concentrate on unused spaces.
\end{abstract}

Keywords: home, land use, London, CLT, new installation .

\section{London}

The article concerns the work of a student competition regarding the topic of home-building. The aim was to develop a concept that is affordable to everyone and flexible enough to allow minimal use of material and land. I participated in the competition with: Lu Chang, Zhao Tianyu and Kata Varjú. The city of London is a metropolis, and a key issue is that with the growth of the city's population - and its expansion - the number of green spaces is decreasing. The competition's aim was not only the establishment of new homes but also the creation of green spaces. The commissioners of the competition did not define a site for the project, the proposals needed to be decided by the competitors. We looked at the project in a vertical manner, not simply to meet the city's specific needs with the building of future homes. We chose a site considering it's relation to public transport, ensuring the city's sustainable transportation. The transportation hubs are more or less fully built around. Therefore we made a conceptional decision putting the houses on top of shopping centres, using their relatively low height and spacious horizontal aspect. This was our architectural answer to the comission's call, using only spaces that are already occupied. As can be seen in the conceptual diagram below, thanks to our way of thinking, the result can be other than just a building that's shaped like a home. (Figure 1.)

The usage of the flat roofs of shopping centres is a rational decision due to the spatial need of buildings. This results in the formation of a new space in the city which in some cases could be above the smog boundaries. This space would be used by cyclists and pedestrians. With the absence of cars at this level, a free pedestrian area could be formed here. In New York, the High Line is an example of this kind of thinking, where the upper levelled traffic spaces were formed into a park.

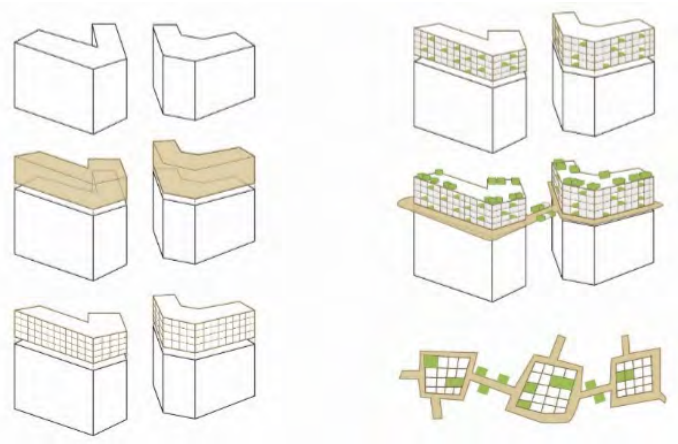

Figure 1. Building concept design 


\subsubsection{Structure}

Having defined the building scene, a decision on structure followed. The installation of the building needed to be done in an economically conscious way thus we decided to use a renewable material which does not damage the environment. We took the utilization of natural values to be important, in order to decrease the size of our ecological footprint and the later maintenance expenses. Our decision rested on CLT (Cross Laminated Timber) which is a glued hardwood structure. The cross-directional glueing of the wood makes the material fully acceptable for load bearing. We formed a wood structure which can accept living boxes that form living spaces according to requirements. The size of the boxes can be adjusted to the family-model and can be placed anywhere in the building. The contour of the building is shaped by the superstructure which is an empty cross-link. The boxes appear in this structure forming the building (Figure 2.)

One of our inspirations was Kurokava Kisho's capsule hotel. In such an expensive metropolis as this, the affordable price could only be achieved with the optimization of living space, thus our aim was to minimise it in such a way that comfort is still achieved. In the design process of the living tower we also tried to make different floor plans to solve variations in needs and preferences. The floor plans are designed in a 2 meter $\times 2$ meter structured modular system assuring that the ap- propriate shape of homes can be fitted into the structure. (Figure 3.)

In our plan, we strived to represent more options for possible apartment placements, facade opportunities, and the design method of apartments based on the number of residents. The diverse design of facades is possible due to variable apartment placements. During our research we have seen similar solutions: a building consisting of home cells that was designed by Dezső Cserba, István Gouth and Jenő Preisinger. Within each flat their system is based on two external and one internal design, however each zone was designed in the same size. During planning, we searched for alternatives that included different opportunities for apartment design, in other words the system of space connection inside the apartments, the connection with green surfaces, and the response to changing demand. The interior of the apartments was designed and formed in a variety of ways, with a modular system in order to satisfy residents. For some of the apartment types we can envisage the complete separation of intimate spaces, however in some cases the separation only occurs as an optical effect. We can envisage an arrival zone at the entrance, and some function connections that merge together, for example the living room could be transformed into a bedroom. For the organization of interiors the opening was a determining factor, in order to provide a sufficient amount of natural light to every room. The designed interiors of apartments define the size of the bounding boxes.
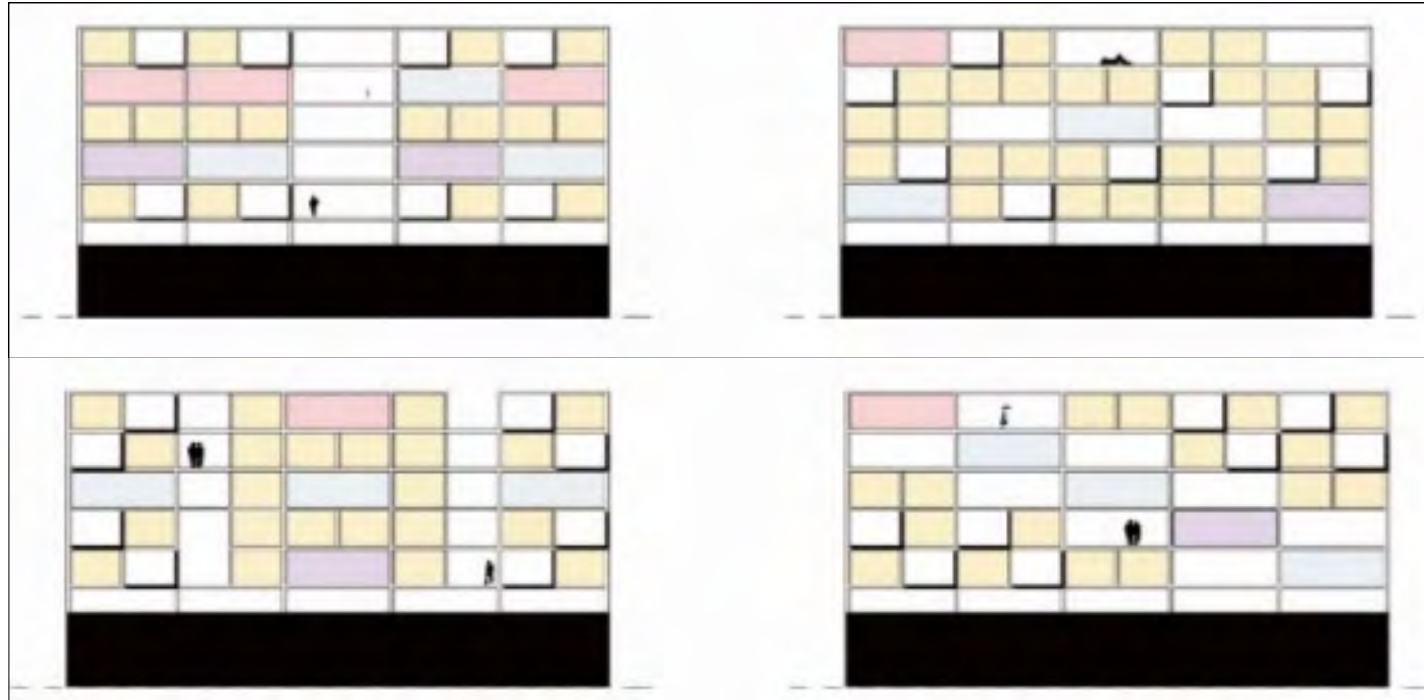

Figure 2. Bulking options 


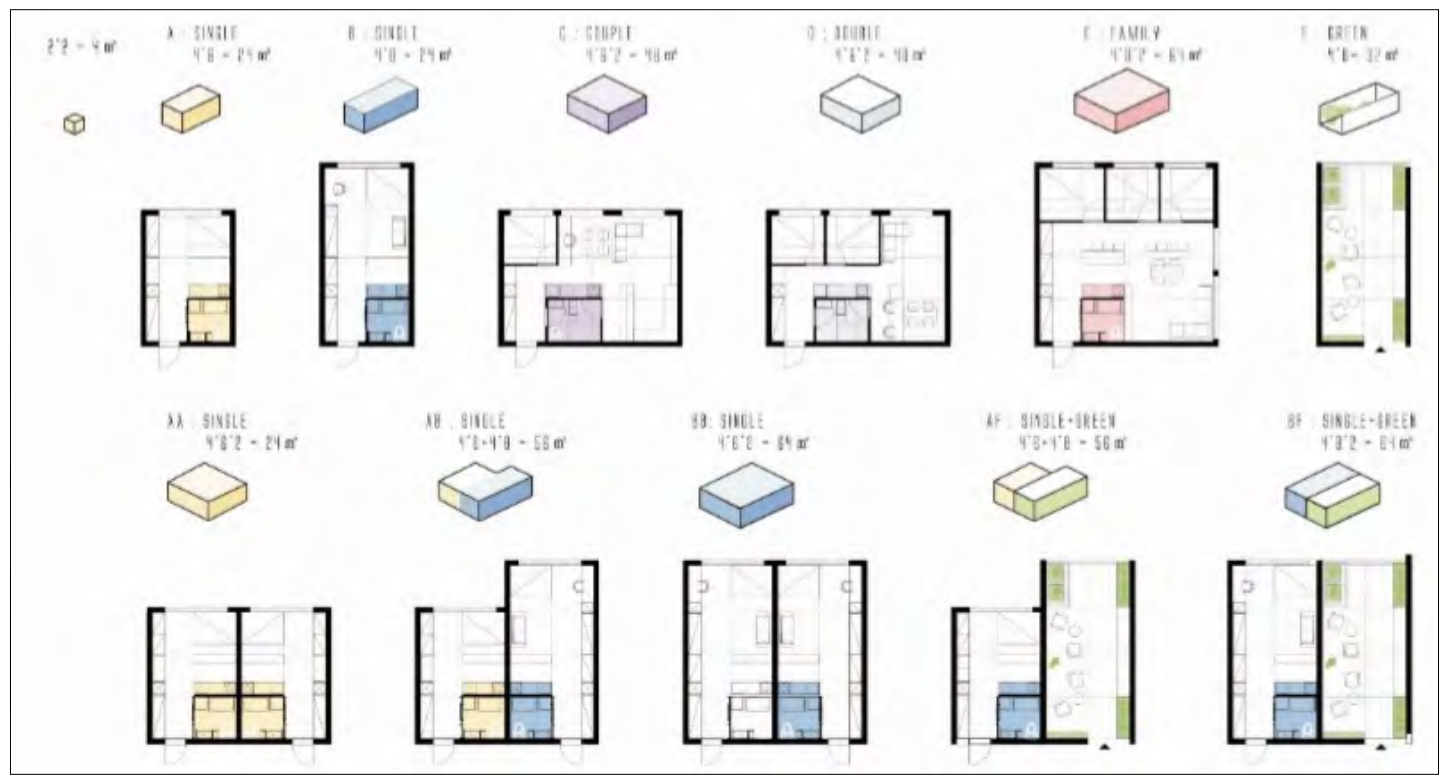

Figure 3. Development of floor plan module system

We believe the eco-conscious design not only important in forming the structure but also in supporting sustainability. We placed wind turbines in the optional facades of the building. The optional use of renewable energy leads to a lower maintenance cost resulting in more affordable homes. (Figure 4.)

Another aim of the project was to also create green-spaces inside the building. We designed green areas inside the structural form which not only affect people's mood but also form a stimulating view. Plants have a positive impact on people's mental and physical health and also have a

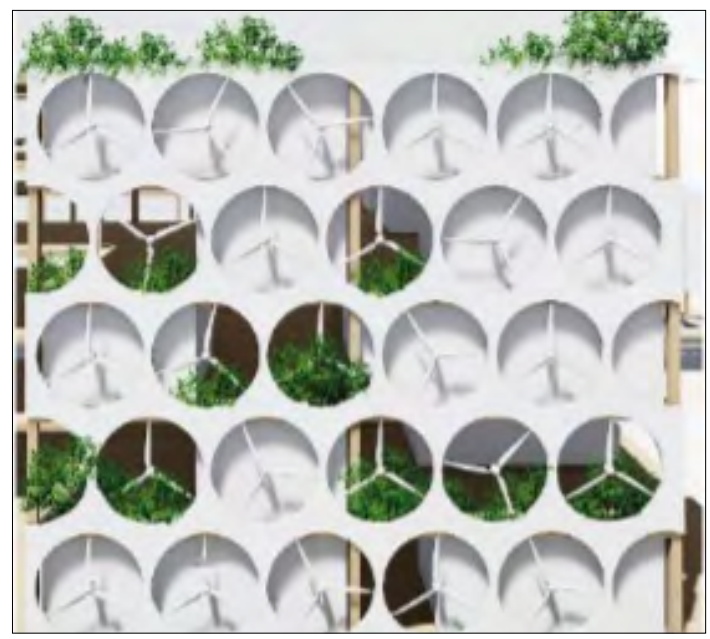

Figure 4. Display of wind turbines and green spaces climatic and dust absorbing quality. These surfaces and the boxes form the facade of the building. The CLT system is a precast building system. It's advantage is that it can be built quickly and precisely. (Figure 5.)

\section{Conclusion}

The design phase was proceeded by research, I also analysed the living conditions of the past and present in Hungarian and international terms. I recorded the advantages and disadvantages of these houses. My aim was to apply my experi-

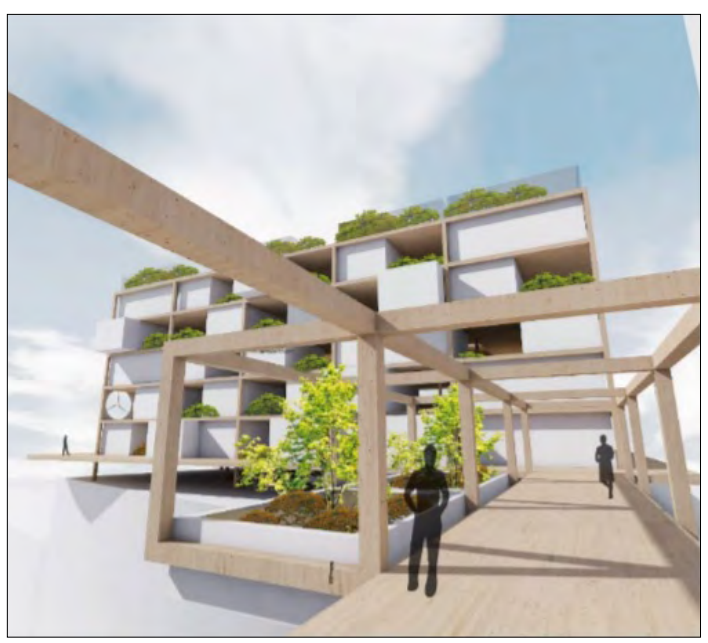

Figure 5. Buildind made with CTL system 
ence from the research and form the houses of the future - even in such untraditional conditions - to be comfortable, anthropocentric and forward-thinking. Every new construction can affect our environment. With the growth of cities we tend to take space from the environment. This is why in our design concept we have tried to use „existing spaces”, forming something new without loosing space elsewhere. We have designed our concept based on intrernational examples gathered from our research, while paying attention to the preservation of traditional values that are combined with modern and contemporary solutions. Today's Metropolitan lifestyle presents new limitations. The number of spaces which can be used for building are continuously decreasing, resulting in higher prices. For affordable house prices the innovation of existing buildings is a key aspect.

\section{Acknowledgement}

Supported BY the ÚNKP-18-2-I-PTE-205 New National Excellence Program of the Ministry of Human Capacities.

\section{References}

[1] Branczik M., Keller M.: Korszerü lakás az óbudai kísérlet 1960. TERC Kft, Nudapest 2011

[2] Pogány F.: A szép emberi környezet. Gondolat könyvkiadó, Budapest, 1976.

[3] Körner Zs., Nagy M.: Az európai és magyar telepszerü lakásépítés története 1945-től napjainkig. TERC Kft., Budapest, 2007.

[4] Kortárs magyar építészet. Többlakásos házak. TERC Kft., Budapest, 2012. 